\title{
Effects of International Diversification and Firm Resources on Firm Performance Risk
}

\author{
Nejat Capar $^{1}$, Ravi Chinta ${ }^{2} \&$ Fiona Sussan ${ }^{2}$ \\ ${ }^{1}$ Meliksah University, Kayseri, Turkey \\ ${ }^{2}$ School of Advanced Studies, University of Phoenix, Phoenix, USA \\ Correspondence: Ravi Chinta, School of Advanced Studies, University of Phoenix, Phoenix, Arizona, USA. E-mail: \\ ravichinta@hotmail.com
}

Received: December 11, 2014

Accepted: December 29, 2014

Online Published: January 5, 2015

doi:10.5430/jms.v6n1p10

URL: http://dx.doi.org/10.5430/jms.v6n1p10

\begin{abstract}
Researchers in international business and strategic management have long been interested in understanding international diversification as a strategy to manage and control firm performance risk. The general argument in this research stream has been arguing that international diversification or multinationality serves as a portfolio diversification strategy that can reduce firm performance risk. However, a major shortcoming of existing studies has been the failure of incorporating firm resources in examining the relationship between international diversification and firm performance risk. Given the importance of firm resources, this study examines the effect of firm resources on firm performance risk relative to that of international diversification. The present study has tested this alternative hypothesis by examining 258 firms over a 5-year period from 13 industries. Results show that it is not international diversification but firm resources such as marketing assets that have a dominant effect on firm performance risk.
\end{abstract}

Keywords: risk, multinationality, R\&D assets, marketing assets

\section{Introduction}

That firm performance is impacted by international diversification has been a subject of considerable research in strategic management and international business (e.g., Buhner, 1987; Daniels \& Bracker, 1989; Delios \& Beamish, 1999; Geringer, Beamish, \& Da Costa, 1989; Geringer, Tallman, \& Olsen, 2000; Gomes \& Ramaswamy, 1999; Grant, 1987; Haar, 1989; Hitt, Hoskisson, \& Kim, 1997; Tallman \& Li, 1996; Zahra et al., 2000; Lu and Beamish, 2001; Hilmersson, 2014). Within this research realm a particular focus of inquiry was directed at firm performance risk (Bettis and Hall, 1982; Bettis and Mahajan, 1985; Jung, 1991; Contractor et al., 2003; Qian et al., 2008). International diversification can be defined as a firm's expansion beyond the borders of its home country across different countries and geographical regions. The terms international diversification, multinationality, and international diversity are often used interchangeably in the literature. This will be also the approach in this paper, although an attempt will be made to use rather the term international diversification for consistency purposes.

This importance of international diversification comes from the fact that it represents a growth strategy (Ansoff, 1965; Chandler, 1962; Rugman et al., 2011; Verbeke and Kano, 2012; Verbeke and Forootan, 2012) that has major potential impact on firm performance. Despite the numerous studies that have examined the association between multinationality and performance, these efforts have provided evidence of conflicting results (Annavarjula \& Beldona, 2000; Contractor et al., 2003; Lu and Beamish, 2004; Thomas and Eden, 2004; Glaum and Oesterle, 2007). Following this, a newer stream of research has focused on potential methodological and theoretical causes that might explain the lack of consistent findings. In this light, some other works have argued that there exists a curvilinear relationship between international diversification and performance as opposed to a linear relationship, which has been the underlying premise in earlier studies (Gomes \& Ramaswamy, 1999; Hitt et al., 1997; Contractor et al., 2003; Lu and Beamish, 2004; Thomas and Eden, 2004; Glaum and Oesterle, 2007).

A major shortcoming of earlier studies, however, is the lack of incorporating firm resources when examining the effect of international diversification on performance as well as the lack of focus on performance risk. According to the resource-based theory, firm resources such as innovative assets and marketing assets can have major effects on firm performance (Barney, 1991; Kotabe, Srinivasan \& Aulakh, 2002; Capar and Kotabe, 2003; Elango and Pattnaik, 
2007). A firm's unique resources may be comprised of things such as capabilities, organizational processes, and experience, among others (Barney, 1991; Elango and Pattnaik, 2007; Verbeke and Forootan, 2012). In this study, the focus is only on innovation and marketing assets. These two resources have been receiving increasing attention in the strategic management literature (e.g., Bettis \& Mahajan, 1985; Johansson and Yip, 1994; Delios \& Beamish, 1999; Kotabe et al., 2002; Rugman et al., 2011). Geographic expansion alone may not reduce performance risk, and other firm level resources such as innovation assets and marketing assets may contribute to reduction of performance risk (Hitt et al., 1997; Kotabe et al., 2002). Therefore, unlike most previous studies on the relationship between international diversification and performance, we are also examining the effect of firm resources while considering the international diversification-performance relationship.

The remainder of the paper is organized as follows: First, a theoretical background and literature review of both the international diversification-performance relationship and the firm resources-performance relationship will be provided. Second, the research methods of the study will be explained. Third, the results will be presented and discussed. Finally, a review of the study will be provided in the conclusion section along with the identification of limitations of the study and possible future directions of inquiry.

\section{Literature Review}

\section{International Diversification and Firm Performance}

International diversification offers several advantages to firms. Several authors argued that international diversification offers prospective market opportunities, which gives firms the opportunity for greater growth (Buhner, 1987; Ruigrok and Wagner, 2003; Contractor, 2007). The most accepted argument for international diversification has been grounded on the theoretical assumption that firms exploit the benefits of internalization in international markets (Caves, 1982; Hymer, 1960; Rugman, 1979, 1981; Verbeke and Kano, 2012; Verbeke and Forootan, 2012). Internalization of markets has advantages such as economies of scale, scope, and learning (Ghoshal, 1987; Kim, Hwang, \& Burgers, 1989, 1993; Kogut, 1985; Contractor, 2007), and sharing core competencies among different business segments and geographic markets (Hamel, 1991; Barney, 1997 and 2001).

Firms with strong competencies that are developed at home can utilize these in international markets (Bartlett \& Ghoshal, 1989; Barney, 1997 and 2001; Elango and Pattnaik, 2007; Kraaijenbrink, 2010). Thus, it is argued that the higher the involvement of a firm in international markets is, the higher will be the exploitation of tangible and intangible resources, which is expected to lead to higher performance and lower performance risk (Hymer, 1960, 1976; Grant, 1987; Kim et al., 1993; Hitt et al., 1997; Kraaijenbrink, 2010). This view is primarily based on the resource or knowledge-based view of the firm in strategic management (Kogut \& Zander, 1993; Nonaka, 1994; Spender, 1996; Kraaijenbrink, 2010), and on internalization theory in the FDI based international business literature (Hymer, 1960; Buckley \& Casson, 1976; Qian et al., 2008; Rugman and Verbeke, 2011).

In addition, multinational firms have the opportunity to integrate their activities across borders by standardizing products, rationalizing production, and allocating their resources more efficiently and effectively (Kobrin, 1991, 1994 and 1997; Ernst and Kim, 2002; Coe et al., 2008). Furthermore, MNCs can gain additional competitive advantages by exploiting market imperfections (e.g., less competitive environment) and cross-border transactions (e.g., transfer pricing), and can also achieve a greater bargaining power with increasing size (Sundaram \& Black, 1992; Caves, 1996; Vidal and Goetschalckx, 2001; Fiss and Hirsch, 2005). All of these arguments support the view that a positive, linear relationship exists between international diversity and performance. While some studies have demonstrated a positive relationship (Daniels \& Bracker, 1989; Haar, 1989; Grant, 1997; Gomes and Ramaswamy, 1999), other studies have shown either a negative relationship or no relationship at all (Siddhartan and Lall, 1982; Kumar, 1984). Most of these studies have assumed that the relationship between international diversification and performance is linear (Gomes \& Ramaswamy, 1999; Thomas and Eden, 2004).

Another stream of studies has examined a non-linear relationship between multinationality and performance, and has argued for a theoretical rationale to justify their position (Hitt et al., 1997; Gomes \& Ramaswamy, 1999; Glaum and Oesterle, 2007). Most of the studies that looked at the relationship between international diversification and performance as curvilinear have not provided a theoretical rationale with the exception of a few. These studies have found a positive relationship, at least up to a certain point (Hill, et al., 1997; Gomes and Ramaswamy, 1999). After a certain point which varies by industry, operations are argued to become more costly as coordination costs outweigh benefits from economies of scale.

It is suggested that higher levels of international diversification, especially combined with product diversification and expansion into markets that are physically and culturally more distant (Davidson, 1983; Papadopoulos and Denis, 
1988; Eramilli, 1991), greatly enhances the transaction costs and information processing demands (Egelhoff, 1982, 1988; Hitt et al, 1994). There are also environmental factors that contribute to the complexity of operations such as government regulations, trade laws, and currency fluctuations (Sundaram and Black, 1992). These transaction costs and the different environmental pressures greatly increase the managerial information processing demands. Thus, to manage the large number of complex transactions and to make sound strategic decisions requires effective structures to handle the information processing demands in an efficient manner.

All of these factors, it is argued, might increase the cost of operations along with increasing levels of international diversity. Thus, the more a firm is diversified internationally, the more complex will be its operations. As a consequence, performance will suffer after a certain point, suggesting an inverted U-shaped curvilinear relationship between international diversity and performance. Results of several studies have demonstrated such evidence, and more specifically they have shown empirical results that after a certain level of international diversification, performance begins to decline (Hitt et al., 1997; Gomes \& Ramaswamy, 1999; Glaum and Oesterle, 2007). The results of these studies imply that while there are benefits of moderate levels of international diversification, there is also transaction costs associated due to the complexities involved of managing such operations.

\subsection{Hypotheses}

Thus, the two effects, linear and non-linear, of international diversification on performance can be summarized in the following two competing hypotheses:

Hypothesis 1: There is a positive and linear relationship between international diversification and performance risk.

Hypothesis 2: There is a non-linear (or curvilinear) relationship between international diversification and performance risk, where performance risk first increases, followed by a decrease with higher levels of international diversification .

\section{Firm resources and performance}

According to the resource-based theory of the firm, firms that possess unique resources achieve competitive advantage and superior performance (Barney, 1991; Wernerfelt, 1984). A firm's unique resources may be comprised of things such as capabilities, organizational processes, and experience, among others (Barney, 1991). In this study, the focus is only on innovation and marketing assets. These two resources have been receiving increasing attention in the strategic management literature (e.g., Bettis \& Mahajan, 1985; Delios \& Beamish, 1999; Kotabe et al., 2002; Rugman et al, 2011; Verbeke and Forooten, 2012). Resources, such as the ability to differentiate a firm's products through innovation and marketing assets, enhance the firm's competitive advantage. Innovation and marketing assets allow firms to achieve some degree of monopoly power ((Bettis \& Mahajan, 1985; Hitt et al., 1997; Hilmersson, 2014).

There have been a number of studies that document a link between investments in innovation assets and new product and process improvement (Stimpert \& Duhaime, 1997; Glaum and Oesterle, 2007). In turn, new product development or improvement allows firms to lower cost or charge higher prices, which leads to higher performance (Tallman and Li, 1996; Stimpert \& Duhaime, 1997; Rugman et al., 2011). The few studies that empirically examined the relationship between firm resources and performance are reviewed below.

Based on the theoretical arguments provided by the resource-based theory of the firm, it can be expected that investing in resources such as innovation and marketing assets should have a positive effect on performance (Barney, 1991; Delios \& Beamish, 1999; Hitt et. al., 1997). According to the resource-based view, a firm's competitive advantage is the result of its unique resources (Barney, 1991; Wernerfelt, 1984). Innovation and marketing assets are resources likely to produce competitive advantage for firms (Hitt et al., 1997; Delios \& Beamish, 1999).

Therefore, the premise is that proprietary assets provide a firm with unique advantages that will affect firm performance positively (Hitt et al., 1997; Delios \& Beamish, 1999). Investing in firm resources allows the firm to differentiate itself vis-à-vis its competitors that allows the firm to charge higher prices, and consequently improve its performance (Stimpert \& Duhaime, 1997; Glaum and Oesterle, 2007). Stimpert and Duhaime noted that "investments that result in new products or improvements in production methods allow businesses to charge higher prices or enjoy lower costs than their rivals" (1997: 568).

Similarly, Bettis and Mahajan (1985) and Hitt et al. (1997) argued that investing in innovation and marketing assets allows the firm to differentiate its products, and therefore affects performance positively. They further suggested that investing in these assets allows the firm to obtain some monopoly power. On the same point, Miller (1973) noted that advertising expenditures create barriers to entry for new competitors due to product differentiation. In other words, 
investing in these resources brings unique advantages similar to Barney's (1991) contention with positive effects on performance.

Innovative assets provide a firm with strong research and development capabilities that can reduce their performance risk by focusing on product design/development and by improving their manufacturing processes. A firm with superior product design gains advantage by differentiating its products from competitors, and can achieve greater returns.

A similar rationale applies to a firm's marketing assets, which allows it to differentiate products and services from competitors and build successful brands. Thus, a firm that spends money on advertising and promoting its products can increase sales both by expanding the sales of the product category and by getting customers to switch to their brands. Firms with strong brand names can charge premium prices in foreign markets to enhance their profitability as well.

Other researchers also have pointed out the performance enhancing characteristics of innovation and marketing assets (Capon et al. 1990; Delios \& Beamish, 1999; Kotabe et al., 2002). For example, Delios and Beamish (1999: 715 ) noted that "proprietary assets provide a firm with unique advantages in its domestic markets and international markets, and thereby augment a firm's performance."

Based on the arguments presented above, we argue that it is rather firm resources such as innovation and marketing assets that affect a firm's performance positively and thereby reduce performance risk, as opposed to solely international diversification. Thus, the following hypotheses are proposed in contrast to $\mathrm{H} 1$ and $\mathrm{H} 2$ :

H3a: Innovation assets have a positive effect on firm performance risk.

$\mathrm{H} 3 \mathrm{~b}$ : Marketing assets have a positive effect on firm performance risk.

\section{Sample and Data}

The data of the study were collected from S\&P Research Insight/Compustat database for a 5-year period between 2009-2013. The decision to use a 5-year time period was based on the rationale of having a long enough time frame required for this study, but at the same keeping the time period limited to avoid excessive missing data. The 5-year data was then averaged in order to reduce the possibility of random effects.

Furthermore, the 2009-2013 period was chosen because it would reflect the time period after the stock market downturn in 2008. Including 2008 when the stock market took a steep downward dive, an extraneous factor, would have added more variability to performance. To be included in the sample, a firm has to meet the following criteria: (1) be a manufacturing firm, (2) have minimum average annual sales of $\$ 100$ million, (3) exist for 6 years, and (4) have complete data available. Consistent with Hitt et al. (1997), the decision to use a $\$ 100$ million cut-off point is to ensure that a firm in the sample has a certain scale, and to overcome the missing data problem that is frequently associated with smaller firms. In contrast, the criterion of having at least 10 percent of foreign sales used in many previous studies was not employed in this study (e.g., Geringer, Beamish \& Da Costa, 1989; Gomes \& Ramaswamy, 1999; Habib \& Victor, 1991; Stopford \& Wells, 1972). It should be noted that including firms with at least $10 \%$ FSTS (Foreign Sales to Total Sales) leads to considerable left-censoring of the data, which can lead to the underestimation of the effect of international diversification on performance. In many cases, this decision rule is applied rather arbitrarily because of the unavailability of data, since firms with a FSTS ratio of less than 10 percent are not required to report their foreign sales according to FASB 14. Just because they are not required to report it doesn't mean they will not. Therefore, firms with less than a $10 \%$ of FSTS ratio will be included in the sample as long as data is available. The purpose is to cover the full range of international diversification. Finally, having complete data available means to have data points for each pair of variables.

Based on the sampling criteria defined above, an initial sample size of 331 was obtained and the analyses were based on a sample size of 258 firms due to missing data.

\subsection{Measures}

Performance Risk. Variability of Return on assets (ROA) was used to measure firm performance risk. Accounting-based measures of performance have been commonly used in strategic management and international business (Grant, 1987; Harr, 1989; Hitt et al., 1997; Vernon, 1971). Variance of these accounting measures has been used as a measure of performance risk (Bettis and Hall, 1982; Bettis and Mahajan, 1985; Jung, 1991). These measures are easily available and they are very informative (Barney, 1997).

International Diversification. Consistent with the majority of previous studies (Grant, 1987; Stopford \& Wells, 1972; Tallman \& Li, 1996), international diversification was operationalized as the ratio of foreign sales to total sales 
(FSTS) in this study. Recently, there have been some arguments in the literature about this measure (Gomes \& Ramaswamy, 1999; Hitt et al., 1997; Ramaswamy, Kroek, \& Renforth, 1996; Sullivan, 1994, 1996). For example, Sullivan (1994) suggested the use of a multidimensional measure consisting of five items, while Ramaswamy et al. (1996) casted serious doubts on this measure based on problems with content validity, criterion validity, and reliability, etc. In turn, Ramaswamy et al. (1996) have suggested the use of a measure containing three (sales, assets, countries) of the five items that Sullivan (1994) suggested.

But because of data availability constraints and comparison purposes, the FSTS was used in this study to measure international diversification.

\section{Firm resources}

Innovation assets. R\&D intensity was used as a proxy for innovation assets. Several studies have shown that this measure is closely related to innovative outputs such as patents and new product introductions (Hitt, Hoskisson, Ireland, \& Harrison, 1991; Hitt, Hoskisson, Johnson, \& Moesel, 1996). R\&D intensity is measured as the ratio of total research and development expenditures to total sales. Various studies on innovation have used R\&D intensity to account for the innovative resources and capability of firms (Baysinger \& Hoskisson, 1989; Caves, 1982; Delios \& Beamish, 1999; Hambrick \& MacMillan, 1985; Hitt et al., 1997; Hoskisson \& Hitt, 1988; Stimpert and Duhaime, 1997). While there is no perfect link between an investment in these resources and the desired outcomes (e.g., innovation, process improvement, etc.), the measures indicate how much is invested in the tangible resources that are logically linked to these outcomes.

Marketing assets. Following Delios and Beamish (1999) and Kotabe et al. (2002), advertising intensity was used as a proxy for marketing assets. It is measured as the ratio of advertising expenditures to total sales. The marketing efforts of firms are commonly assessed through advertising intensity since firms often avoid disclosing their total marketing expenditures (Capon, Farley, and Hoenig, 1990; Kotabe et al., 2002). As it is with R\&D intensity, advertising intensity is not a perfect representation of marketing assets, but they show a firm's attempt to differentiate its products (Kotabe et al., 2002).

Control variables. Several control variables were used in the study following Grant et al. (1988) and Hitt et al. (1997) among others. These are firm size, industry effects, and financial leverage. Firm size, measured by the natural logarithm of total sales, is used to control for the potential effect of scale economy differences. Prior research has shown industry effects to have important effects on cross-sectional variation of firm performance (Schmalensee, 1985). Some studies use industry dummy variables (Grant et al, 1988), others use industry characteristics (Robins \& Wiersema, 1995; Tallman \& Li, 1996). In this study, possible industry effects are controlled by using industry dummy variables based on each firm's primary two-digit industry (Hitt et al., 1997). Capital structure also has been argued to affect firm performance (Hitt \& Smart, 1994; Simerly \& Li, 2000). Per theories in finance, the amount of debt has a direct impact on performance risk of any firm. Firm leverage is operationalized as the percentage of long-term debt to total capital (debt plus equity). Finally, industry effects were controlled for using dummy variables.

\section{Data Analysis}

The international diversification and firm resources (i.e., innovation and marketing assets) hypotheses were tested in two models as illustrated in the two regression equations presented below, that is the linear effect versus the curvilinear effect of international diversification on firm performance, were tested by OLS regression method. Both the linear and curvilinear models include the main effects of innovation and marketing assets.

$$
\begin{gathered}
\text { PerfRisk }=\beta_{0}+\beta_{1} \text { Size }+\beta_{2} \text { FL }+\beta_{3} \text { RD }+\beta_{4} \text { AD }+\beta_{5} \text { Intl. Div. }+\mathrm{e} \\
\text { PerfRisk }=\beta_{0}+\beta_{1} \text { Size }+\beta_{2} \text { FL }+\beta_{3} \text { RD }+\beta_{4} \text { AD }+\beta_{5} \text { Intl. Div }+\beta_{6} \text { Intl. Div. }{ }^{2}+\mathrm{e}
\end{gathered}
$$

As can be seen, equation (1) represents the linear model, while equation (2) represents the curvilinear model, where the Intl. Div. ${ }^{2}$ will be entered to test for curvilinearity. The curvilinear model will be supported if the $\mathrm{R}^{2}$ associated with the curvilinear model (Equation 2) is higher than the linear model (Equation 1), and the coefficient of the squared term for international diversification (Intl. Div.) variable, $\beta_{6}$, is significant. In turn, the hypotheses (H3a and $\mathrm{H} 3 \mathrm{~b}$ ) about the two firm resources will be supported if the coefficients $\beta_{3}$ and $\beta_{4}$ of innovation assets and marketing assets, respectively, are found statistically significant.

\section{Results}

Table 1 below reports means, standard deviations, and the bivariate correlations for the variables used in the study. The correlations among the variables present no problem of multicollinearity. 
Table 1. Means, standard deviation and correlations $\mathrm{s}^{\mathrm{a}}$

\begin{tabular}{|c|c|c|c|c|c|c|c|c|}
\hline Variables & Means & S.D. & 1 & 2 & 3 & 4 & 5 & 6 \\
\hline \multicolumn{9}{|l|}{ 1. Performance Risk } \\
\hline (ROARisk) & 0.05 & 0.06 & 1 & & & & & \\
\hline 2. Firm Size (size) & 8.21 & 1.42 & $-0.43 * * *$ & 1 & & & & \\
\hline 3. Leverage (Levg.) & 2.71 & 1.56 & -0.10 & $0.35^{* *}$ & 1 & & & \\
\hline 4. Innovation Assets (Innov.) & 0.06 & 0.11 & $0.80 * * *$ & $-0.42 * * *$ & $-0.21 * *$ & 1 & & \\
\hline 5. Marketing Assets (Markt.) & 0.02 & 0.03 & 0.09 & 0.10 & -0.03 & -0.10 & 1 & \\
\hline \multicolumn{9}{|l|}{ 6. International Diversification } \\
\hline (ID) & 0.32 & 0.19 & -0.12 & $0.23 * *$ & -0.06 & 0.04 & 0.03 & 1 \\
\hline \multicolumn{9}{|l|}{ a $\quad N=258$} \\
\hline \multicolumn{9}{|l|}{${ }^{*} \mathrm{p}<0.05$} \\
\hline \multicolumn{9}{|l|}{${ }^{* *} \mathrm{p}<0.01$} \\
\hline$*^{* * *} \mathrm{p}<0.001$ & & & & & & & & \\
\hline
\end{tabular}

Table 2 presents the results for both the linear model and the curvilinear model of the relationship between international diversification, firm resources and performance.

Table 2. Effect of firm resources and intl. diversification on performance risk (ROARisk)

\begin{tabular}{|c|c|c|}
\hline Independent Variables & Linear Model & Curvilinear Model \\
\hline Intercept & $0.054 * * *$ & $0.058 * * *$ \\
\hline Firm Size (size) & -0.09 & -0.09 \\
\hline Financial Leverage (FL) & $-0.27 * * *$ & $-0.27 * * *$ \\
\hline Innovation Assets (RD) & $0.688 * * *$ & $.685^{* * *}$ \\
\hline Marketing Assets (AD) & $-0.315^{* * *}$ & $-0.308 * * *$ \\
\hline Intl. Diversification (ID) & -0.06 & -0.15 \\
\hline Intl. $\operatorname{Div}^{2}\left(\mathrm{ID}^{2}\right)$ & & 0.09 \\
\hline Adj. $R^{2}$ & 0.66 & 0.66 \\
\hline $\mathrm{F}$ & $69.0 * * *$ & $57.37 * * *$ \\
\hline \multicolumn{3}{|l|}{${ }^{*} \mathrm{p}<0.05$} \\
\hline \multicolumn{3}{|l|}{${ }^{* *} \mathrm{p}<0.01$} \\
\hline${ }^{* * *} \mathrm{p}<0.001$ & & \\
\hline
\end{tabular}

The first equation in Table 2 is an examination of the linear effect of international diversification on ROA including the effects of innovative and marketing assets. As can be seen, there is no statistically significant relationship between international diversification (ID) and performance. This result is rather inconsistent with findings of other studies (Hitt, Hoskisson, \& Kim, 1997; Delios \& Beamish, 1999; Gomes \& Ramaswamy, 1999). The overall model is also significant at the $\mathrm{p}<.001$ level, with an Adj. $\mathrm{R}^{2}$ of .66 . Among the control variables, only financial leverage (FL) was statistically significant and had a negative slope coefficient.

The second equation in Table 2 shows that there is also no support for the hypothesis that there is a U-shaped relationship (curvilinear effect) between international diversification and firm performance. As can be seen, the coefficient of the squared international diversification term $\left(\mathrm{ID}^{2}\right), .09$ is statistically not significant. The sign of the 
linear effect becomes negative in the second model while the sign of the curvilinear effect is positive, indicating a potential inverted U-shaped relationship albeit lacking statistical significance.

In other words, the explanatory power of the model has not changed significantly when the squared term of international diversification, $\mathrm{ID}^{2}$, entered the model. As can be seen in Table 2, the adjusted $\mathrm{R}^{2}$ does not change from the linear model to the curvilinear model. This indicates that the curvilinear model doesn't fit the data better than the linear model. The findings indicate that neither H1, nor H2 is supported in this study. The results of our study doesn't confirm recent findings by Gomes \& Ramaswamy (1999) and by Hitt, Hoskisson, \& Kim (1997) and others, who found evidence in favor of either a linear or an inverse U-shaped curvilinear relationship between international diversity and firm performance for manufacturing firms. In either case, it might be premature to quickly claim a universal positive effect of international diversification on firm performance.

With respect to H3a and H3b, only H3b is supported in both models while H3a is supported in both models in the opposite direction than hypothesized. The coefficient of marketing assets in the linear model is -0.315 , and -0.308 in the curvilinear model, both statistically significant $(\mathrm{p}<0.01)$. In other words, marketing assets have a statistically significant effect on firm performance in both models. In contrast, the innovation assets coefficients of 0.688 and 0.685 in the two models were statistically significant $(\mathrm{p}<0.01)$ but in the opposite direction. Thus, H3a is not supported as hypothesized, but the opposite relationship is empirically validated. That is, more R\&D intense global firms experience higher performance risk.

\section{Discussion}

These results provide partial support to the main argument put forward in this paper. It has become widely accepted that international diversification has a positive effect on firm performance, whether this relationship has a linear or non-linear form. From a theoretical perspective, this supports the arguments put forward by both internalization theory and resource-based theory. Accordingly, firms diversify internationally to exploit their resources or proprietary assets. Without the possession of such resources, there wouldn't be any significant performance effects of international diversification (e.g., Kotabe et al., 2002). In contrast, Delios and Beamish (1999) in their study of Japanese firms, were able to demonstrate independent main effects due to international diversification. However, their study is rather an exception at the time and is not based on U.S. firms as the majority of earlier studies in this area, are. It is apparent that more studies are needed to understand whether there are performance benefits to international diversification independent of firm resources.

\section{Conclusion}

The main contribution of this paper is that it empirically examined the relationship between international diversification and performance risk while at the same time examining the effect of firm resources. Previous studies that have examined the international diversification-performance risk relationship largely ignored firm resources in their models. It has been argued in this paper that it is largely a firm's resources that have an ameliorative effect on firm performance risk and not international diversification. The findings of this study partially support this claim in that the effect of international diversification didn't have a significant effect on performance risk when firm resources were included in the model(s).

The study also has a number of limitations. First of all, international diversity was measured by a single indicator only, namely the foreign sales to totals sales ratio. Ideally, it is desirable to have multiple or different indicators to capture the international activities of firms more fully. However, limitations in data availability hindered this attempt. Second, the study was based on a sample of U.S. manufacturing firms. Thus, generalization to firms from other countries and industries (i.e., service industries) should be made with caution.

A further limitation of our study is that we were not able to include, due to data unavailability, a number of potentially relevant variables such as the extent of bottom-of-the-pyramid markets. As such, future studies could include product diversity as a moderator variable. As demonstrated by Hitt, Hoskisson, \& Kim (1997), the relationship between geographic market diversity and performance is moderated by product diversity.

In conclusion, this paper examined the effects of firm resources and international diversification on firm performance using a sample of 258 U.S. manufacturing firms. No evidence was found in favor of either a linear or curvilinear relationship between international diversification and performance. However, marketing assets were found to have a negative and statistically significant effect on performance risk. That is, marketing intensity reduces performance risk. In contrast, innovation assets were found to have a positive and statistically significant effect on performance risk. That is, $R \& D$ intensity increases performance risk. It is apparent that further studies are needed in order to examine more closely the effects of firm resources and international diversification on firm performance. The 
interplay between geographic diversification and deployment of innovation and marketing assets contributes to the impact on performance risk for multinational firms. It is hoped that the current paper empirically presents the interplay and is a step in this direction.

\section{References}

Annavarjula, Madan., \& Sam, Beldona. (2000). Multinationality-Performance relationship: A review and reconceptualization. International Journal of Organizational Analysis, 8(1), 48-67. http://dx.doi.org/10.1108/eb028910

Ansoff, Igor. H. (1965). Corporate strategy: An analytic approach to business policy for growth and expansion. McGraw Hill.

Barney, J. B. (1997). Gaining and sustaining competitive advantage, p. 145. Reading, MA: Addison-Wesley.

Barney, J. B. (2001). Is the resource-based "view" a useful perspective for strategic management research? Yes. Academy of Management Review, 26(1), 41-56.

Barney, Jay. (1991). Firm resources and sustained competitive advantage. Journal of Management, 17(1), 99-120. http://dx.doi.org/10.1177/014920639101700108

Bartlett, Christopher, A., \& Sumantra, Ghoshal. (1989). Managing across borders: The transnational solution. Boston: Harvard Business School Press.

Bettis, R. A., \& Hall, W. K. (1982). Diversification strategy, accounting determined risk, and accounting determined return. Academy of Management Journal, 25, 254-264. http://dx.doi.org/10.2307/255989

Bettis, R. A., \& Mahajan, V. (1985). Risk/return performance of diversified firms. Management Science, 31, 785-799. http://dx.doi.org/10.1287/mnsc.31.7.785

Boyacigiller, Nakiye, A., \& Nancy, J. Adler. (1991). The parochial dinosaur: Organizational science in a global context. Academy of Management Review, 16(2), 262-290.

Buckley, Peter J., \& Mark, Casson. (1976). The future of the multinational enterprise. Holmes and Meier Publishers, New York, NY.

Buhner, Rolf. (1987). Assessing international diversification of West German corporations. Strategic Management Journal, 8(1), 25-37. http://dx.doi.org/10.1002/smj.4250080104

Capar, N., \& Kotabe, M. (2003). The relationship between international diversification and performance in service firms. Journal of International Business Studies, 34(4), 345-355. http://dx.doi.org/10.1057/palgrave.jibs.8400036

Caves, R. E. (1996). Multinational enterprise and economic analysis. Cambridge University Press.

Caves, Richard E. (1982). Multinational enterprise and economic analysis. Cambridge: Cambridge University Press.

Chandler, Alfred D. (1962). Strategy and structure: Chapters in the history of American industrial enterprise. Cambridge, MA: MIT Press.

Coe, N. M., Dicken, P., \& Hess, M. (2008). Global production networks: realizing the potential. Journal of Economic Geography, 8(3), 271-295. http://dx.doi.org/10.1093/jeg/lbn002

Contractor, F. J. (2007). Is international business good for companies? The evolutionary or multi-stage theory of internationalization vs. the transaction cost perspective. Management International Review, 47(3), 453-475. http://dx.doi.org/10.1007/s11575-007-0024-2

Contractor, F. J., Kundu, S. K., \& Hsu, C. C. (2003). A three-stage theory of international expansion: The link between multinationality and performance in the service sector. Journal of International Business Studies, 34(1), 5-18. http://dx.doi.org/10.1057/palgrave.jibs.8400003

Daniels, John D., \& Jeffrey Bracker, (1989). Profit performance: Do foreign operations make a difference? Management International Review, 29(1), 46-56.

Davidson, William H. (1983). Market similarity and market selection: Implications for international marketing strategy. Journal of Business Research, 11(4), 439-456. http://dx.doi.org/10.1016/0148-2963(83)90004-8

Delios, Andrew, \& Paul W. Beamish. (1999). Geographic scope, product diversification and the corporate performance of Japanese firms. Strategic Management Journal, 20(8), 711-727. http://dx.doi.org/10.1002/(SICI)1097-0266(199908)20:8<711::AID-SMJ41>3.0.CO;2-8 
Egelhoff, William G. (1982). Strategy and structure in multinational corporations: An information processing approach. Administrative Science Quarterly, 27(3), 435-458. http://dx.doi.org/10.2307/2392321

Elango, B., \& Pattnaik, C. (2007). Building capabilities for international operations through networks: a study of Indian firms. Journal of International Business Studies, 38(4), 541-555. http://dx.doi.org/10.1057/palgrave.jibs.8400280

Ernst, D., \& Kim, L. (2002). Global production networks, knowledge diffusion, and local capability formation. Research Policy, 31(8), 1417-1429. http://dx.doi.org/10.1016/S0048-7333(02)00072-0

Fiss, P. C., \& Hirsch, P. M. (2005). The discourse of globalization: Framing and sensemaking of an emerging concept. American Sociological Review, 70(1), 29-52. http://dx.doi.org/10.1177/000312240507000103

Franko, Lawrence G. (1976). The European multinationals: A renewed challenge to American and British big business. Stamford, CT: Greylock Publishing.

Geringer, J. Michael., Paul W. Beamish, \& Richard C. DaCosta. (1989). Diversification strategy and internationalization: Implications for MNE performance. Strategic Management Journal, 10(2), 109-119. http://dx.doi.org/10.1002/smj.4250100202

Geringer, Michael J., Stephen Tallman, \& David M Olsen. (2000). Product and international Diversification among Japanese multinational firms. Strategic Management Journal, 21(1), 51-80. http://dx.doi.org/10.1002/(SICI)1097-0266(200001)21:1<51::AID-SMJ77>3.0.CO;2-K

Ghoshal, Sumantra. (1987). Global strategy: An organizing framework. Strategic Management Journal, 8(5), 425-440. http://dx.doi.org/10.1002/smj.4250080503

Glaum, M., \& Oesterle, M. J. (2007). 40 years of research on internationalization and firm performance: more questions than answers?. Management International Review, 47(3), 307-317. http://dx.doi.org/10.1007/s11575-007-0018-0

Gomes, Lenn, \& Kannan, Ramaswamy. (1999). An empirical examination of the form of the relationship between multinationality and performance. Journal of International Business Studies, 30(1), 173-188. http://dx.doi.org/10.1057/palgrave.jibs. 8490065

Grant, Robert. M. (1987). Multinationality and performance among British manufacturing companies. Journal of International Business Studies, 18(3), 79-89. http://dx.doi.org/10.1057/palgrave.jibs.8490413

Haar, Jerry. (1989). A comparative analysis of the profitability performance of the largest U.S., European and Japanese multinational enterprises. Management International Review, 29(3), 5-18.

Habib, Mohammed M., \& Bart Victor. (1991). Strategy, structure, and performance of U.S. manufacturing and service MNCs: A comparative analysis. Strategic Management Journal, 12(8), 589-606. http://dx.doi.org/10.1002/smj.4250120803

Hamel, Gary. (1991). Competition for competence and interpartner learning within international strategic alliances. Strategic Management Journal, 12(Summer), 83-103. http://dx.doi.org/10.1002/smj.4250120908

Hilmersson, M. (2014). Small and medium-sized enterprise internationalisation strategy and performance in times of market turbulence. International Small Business Journal, 32(4), 386-400. http://dx.doi.org/10.1177/0266242613497744

Hitt, Michael A., Robert E. Hoskisson, \& Duane R. Ireland. (1994). A mid-range theory of the interactive effects of international and product diversification on innovation and performance. Journal of Management, 20(2), 297-326. http://dx.doi.org/10.1016/0149-2063(94)90018-3

Hitt, Michael. A., Robert E. Hoskisson, \& Hicheon Kim. (1997). International diversification: Effects on innovation and firm performance in product-diversified firms. Academy of Management Journal, 40(4), 767-798. http://dx.doi.org/10.2307/256948

Hymer, Stephen H. (1976). A study of direct foreign investment. Cambridge, MA: MIT Press.

Johanson, Jan, \& Jan-Erik Vahlne. (1977). The internationalization process of the firm: A model of knowledge development and increasing foreign commitments. Journal of International Business Studies, 8(1), 23-32. http://dx.doi.org/10.1057/palgrave.jibs.8490676

Johansson, J. K., \& Yip, G. S. (1994). Exploiting globalization potential: US and Japanese strategies. Strategic Management Journal, 15(8), 579-601. http://dx.doi.org/10.1002/smj.4250150802 
Jung, Y. (1991). Multinationality and profitability. Journal of Business Research, 23, 179-187. http://dx.doi.org/10.1016/0148-2963(91)90027-U

Katrishen, Frances A., \& Nicos A. Scordis. (1998). Economies of scale in services: A study of multinational insurers. Journal of International Business Studies, 29(2), 305-324. http://dx.doi.org/10.1057/palgrave.jibs.8490038

Kim, Chan W., Peter Hwang, \& Willem P. Burgers. (1989). Global diversification strategy and corporate profit performance. Strategic Management Journal, 10(1), 45-57. http://dx.doi.org/10.1002/smj.4250100105

Kim, Chan W., Peter Hwang, \& Willem P. Burgers. (1993). Multinationals' diversification and the risk-return trade-off. Strategic Management Journal, 14(4), 275-286. http://dx.doi.org/10.1002/smj.4250140404

Kobrin, S. J. (1994). Is there a relationship between a geocentric mind-set and multinational strategy?. Journal of International Business Studies, 493-511. http://dx.doi.org/10.1057/palgrave.jibs.8490209

Kobrin, S. J. (1997). The architecture of globalization: State sovereignty in a networked global economy. Governments, Globalization and International Business. Oxford University Press, London etc.

Kobrin, Stephen J. (1991). An empirical analysis of the determinants of global integration. Strategic Management Journal, 12(special issue), 17-37. http://dx.doi.org/10.1002/smj.4250120904

Kogut, Bruce, \& Udo Zander. (1993). Knowledge of the firm and the evolutionary theory of the multinational corporation. Journal of International Business Studies, 24(4), 625-645. http://dx.doi.org/10.1057/palgrave.jibs.8490248

Kogut, Bruce. (1985). Designing global strategies: Profiting from operating flexibility. Sloan Management Review, 27(1), 27-38.

Kotabe, Masaaki, Srini S. Srinivasan, \& Preet S. Aulakh. (2002). Multinationality and firm performance: The moderating role of marketing and R\&D activities. Journal of International Business Studies, 33(1), 79-97. http://dx.doi.org/10.1057/palgrave.jibs. 8491006

Kraaijenbrink, J., Spender, J. C., \& Groen, A. J. (2010). The resource-based view: a review and assessment of its critiques. Journal of Management, 36(1), 349-372. http://dx.doi.org/10.1177/0149206309350775

Kumar, Manmohan S. (1984). Growth, acquisition and investment. Cambridge, U.K.: Cambridge University Press.

Lu, J. W., \& Beamish, P. W. (2001). The internationalization and performance of SMEs. Strategic Management Journal, 22(2), 565-586. http://dx.doi.org/10.1002/smj.184

Lu, J. W., \& Beamish, P. W. (2004). International diversification and firm performance: The S-curve hypothesis. Academy of Management Journal, 47(4), 598-609. http://dx.doi.org/10.2307/20159604

Nonaka, Ikujiro. (1994). A Dynamic Theory of Organizational Knowledge Creation. Organization Science, 5(1), 14-37. http://dx.doi.org/10.1287/orsc.5.1.14

Qian, G., Li, L., Li, J., \& Qian, Z. (2008). Regional diversification and firm performance. Journal of International Business Studies, 39(2), 197-214. http://dx.doi.org/10.1057/palgrave.jibs.8400346

Ramaswamy, Kannan, Galen K. Kroeck, \& William Renforth. (1996). Measuring the degree of internationalization of a firm: A comment. Journal of International Business Studies, 27(1), 167-178. http://dx.doi.org/10.1057/palgrave.jibs.8490131

Rugman, A. M., Verbeke, A., \& Nguyen, P. C. Q. T. (2011). Fifty years of international business theory and beyond. Management International Review, 51(6), 755-786. http://dx.doi.org/10.1007/s11575-011-0102-3

Rugman, Alan. M. (1981). Inside the multinationals: The economics of international markets. London: Croom Helm.

Ruigrok, W., \& Wagner, H. (2003). Internationalization and performance: An organizational learning perspective. Management International Review, 63-83.

Siddhartan, N. S., \& Sanjaya Lall. (1982). Recent growth of the largest U.S. multinationals. Oxford Bulletin of Economics and Statistics, 44(1), 1-13. http://dx.doi.org/10.1111/j.1468-0084.1982.mp44001001.x

Spender, J-C. (1996). Making Knowledge the Theory of a Firm. Strategic Management Journal, 17, 45-62. http://dx.doi.org/10.1002/smj.4250171106

Stopford, John. M., \& Wells, Louis. T. (1972). Managing the multinational enterprise. New York, NY: Basic Books. 
Sullivan, Daniel. (1994). Measuring the degree of internationalization of a firm. Journal of International Business Studies, 25(2), 325-342. http://dx.doi.org/10.1057/palgrave.jibs.8490203

Tallman, Stephen, \& Jiatao Li. (1996). Effects of international diversity and product diversity on the performance of multinational firms. Academy of Management Journal, 39(1), 179-196. http://dx.doi.org/10.2307/256635

Thomas, D. E., \& Eden, L. (2004). What is the shape of the multinationality-performance relationship?. Multinational Business Review, 12(1), 89-110. http://dx.doi.org/10.1108/1525383X200400005

Verbeke, A., \& Forootan, M. Z. (2012). How Good are Multinationality-Performance Empirical Studies?. Global Strategy Journal, 2(4), 332-344. http://dx.doi.org/10.1111/j.2042-5805.2012.01040.x

Verbeke, A., \& Kano, L. (2012). An internalization theory rationale for MNE regional strategy. Multinational Business Review, 20(2), 135-152. http://dx.doi.org/10.1108/15253831211238212

Vidal, C. J., \& Goetschalckx, M. (2001). A global supply chain model with transfer pricing and transportation cost allocation. European Journal of Operational Research, 129(1), 134-158. http://dx.doi.org/10.1016/S0377-2217(99)00431-2

Zahra, S. A., Ireland, R. D., \& Hitt, M. A. (2000). International expansion by new venture firms: International diversity, mode of market entry, technological learning, and performance. Academy of Management Journal, 43(5), 925-950. http://dx.doi.org/10.2307/1556420 